\title{
Twenty-Year of Cooperation
}

\author{
Tsuneyuki Morita
}

At the end of this 3-year project (Japan Society for the Promotion of Science (JSPS) Core-to-Core Program "New Horizons in Asian Museums and Museology") to advance the mutual collaboration of museum studies and practices in Asian countries, particularly Mongol, Myanmar, Thailand and Japan, I would like to express my delight at the fruitful gains made through sincere discussions.

Practically speaking, our project got underway 20 years ago, when the first international museology program was organized, featuring collaboration with National Museum of Ethnology, Japan (Minpaku) and the Japan International Cooperation agency (JICA). Three foreign participants at the present meeting, Ms. Jarunee Incherdchai, Mr. Ichinkhorloo Lkhagvasuren, and Ms. Nu Mra Zan, also joined in that program. At the time, some of us were instructors and above the three were students, but we are now warmer friends and colleagues. One of the unofficial purposes of the program and something which I personally expected as head of the steering committee was to cement closer links among museum professionals from various countries. Since that time, some of the seeds you brought back to your home countries have spawned thriving flowers all around the world. The younger members who participated in the same program in recent years surely supported this initiative. Of course, all countries have their own cultural background, so we showed you some ideas and numerous results from our own trial and error approach to use as a reference in your new activities. During the actual 3-day international symposium, we also learned a lot from you and were able to check and review the activities performed over our last 20 years of activities.

Museology only emerged as recently as the second quarter of the twentieth century in Europe and North America, at which time all Asian, African, South

\footnotetext{
T. Morita $(\bowtie)$

National Museum of Ethnology, Senri Expo Park, Suita, Osaka 565-8511, Japan

e-mail:mhf01623@nifty.ne.jp
} 
American and other areas were off limits for discussion in all respects. This might be inevitable, because most of those countries were colonies or semi-colonial states of Great Powers - a fact which led to a yawning chasm in international museum standards. So-called global standards only apply to target areas and most of the conditions in other areas were neglected. The museum, particularly in Asian countries, is demanded to find a local standard rather than respecting the "global standard."

We believe that the present project represents a positive trial occasion to reveal our own standard in Asia.

Open Access This chapter is distributed under the terms of the Creative Commons AttributionNonCommercial 4.0 International License (http://creativecommons.org/licenses/by-nc/4.0/), which permits any noncommercial use, duplication, adaptation, distribution and reproduction in any medium or format, as long as you give appropriate credit to the original author(s) and the source, provide a link to the Creative Commons license and indicate if changes were made.

The images or other third party material in this chapter are included in the work's Creative Commons license, unless indicated otherwise in the credit line; if such material is not included in the work's Creative Commons license and the respective action is not permitted by statutory regulation, users will need to obtain permission from the license holder to duplicate, adapt or reproduce the material. 